ZOOLOGIA 27 (6): 979-985, December, 2010

doi: $10.1590 /$ S1984-46702010000600021

\title{
Cephalic salivary glands of two species of advanced eusocial bees (Hymenoptera: Apidae): morphology and secretion
}

\author{
Silvana B. Poiani' ${ }^{1,2} \&$ Carminda da Cruz-Landim ${ }^{1}$
}

\author{
Departamento de Biologia, Instituto de Biociências, Universidade Estadual Paulista. Avenida 24A 1515, Bela Vista, \\ 13506-900 Rio Claro, São Paulo, Brasil. \\ 2 Corresponding author. E-mail: spoiani@yahoo.com
}

\begin{abstract}
Some adult eusocial bees have a pair of cephalic salivary glands (CSG) in addition to the thoracic labial or salivary gland pairs. This paper deals with variations in morphological features and secretion production of the CSG of females and males of Apis mellifera Linnaeus, 1758 and Scaptotrigona postica Latreille, 1807. The following life stages were studied: newly emerged, nurse, and forager workers; newly emerged and egg-laying queens; and newly emerged and sexually mature males. The histological results showed that the CSG differs between the two species in the following features: while alveoli and duct cells are cuboidal in workers and queens of $A$. mellifera, they change from cuboidal to flat in S. postica as the workers age. The glands of newly emerged males and females of $A$. mellifera are similar. However, as males become sexually mature, glands degenerate and practically disappear. The secretion from the glands of females of both species is oleaginous and gradually accumulates in the lumen of the alveoli in the beginning of the adult phase. Consequently, forager workers and egg-laying queens exhibit more turgid alveoli than younger individuals. Sudan black and Nile's blue staining indicated that the CSG secretion consists of neutral lipids. The possible role of gland secretion is discussed taking in account tasks performed by the individuals in the particular phases studied.
\end{abstract}

KEY WORDS. Apis mellifera; histochemical; labial gland; lipid; Scaptotrigona postica.

Apinae contain eusocial bees such as Apis mellifera Linnaeus, 1758 and Scaptotrigona postica Latreille, 1807. Adult bees have one pair of salivary or labial glands in the thorax. Apinae bee species have an additional, cephalic salivary gland pair. Thoracic and cephalic salivary glands release a secretion in the tongue proboscis through a common excretory duct (SNOdgrass 1956, Cruz-LANDim 1967). Both pairs of glands develop during the pupal phase from evaginations of the excretory duct of the larval salivary glands (SNODgrass 1956, CruzLANDim \& MeLLo 1967).

Although thoracic and cephalic salivary glands have a common origin, they have different morphologies and secrete different substances. Species of Bombus Latreille, 1802 and Meliponinae have a salivary pouch or reservoir where the thoracic and cephalic ducts meet to form the common excretory duct. This pouch is absent in A. mellifera (Cruz-Landim 1967). According to SiMPSON (1960), Simpson et al. (1968) and Delage-Darchen, et al. (1979) the secretion of the thoracic gland is aqueous and contains digestive enzymes, whereas the cephalic gland produces an oily secretion that helps with wax manipulation (HeselHaus 1922), lubrication of the mouthparths (SIMPSON 1960) and scent trail demarcation (JARAu et al. 2004, Schorcopf et al. 2007).

The final degree of development of the cephalic salivary gland differs between the sexes and also among bee species.
For example, A. mellifera workers and queens have well-developed glands that stand in contrast with the vestigial or absent cephalic gland of males (Kratky 1931, Simpson 1962, Graf 1968). In species of Bombus, on the other hand, the cephalic salivary gland is more developed in males (Kullenberg et al. 1973, Lauer 1992, Bergman \& Bergström 1997).

Few studies have been conducted on the morphology and function of the cephalic salivary gland, and most of the existing contributions have not focused on how changes in gland development relate with functional changes in workers, queens and males. In an attempt to elucidate and compare the function of the cephalic salivary gland of $A$. mellifera and $S$. postica, this study analyzes the morphologic variations and secretion dynamics of this gland in females and males that perform distinct activities within the colony in these species.

\section{MATERIAL AND METHODS}

We analyzed newly emerged (young), nurses (middle-age) and forager (old) workers, virgin (young) and egg-laying (mature) queens of $A$. mellifera and $S$. postica. Additionally, we also included newly emerged and sexually mature males of $A$. mellifera in our samples. 
For light microscopy visualization, the cephalic salivary glands (CSG) from workers and queens of both species and males of $A$. mellifera were dissected in buffered saline solution for insects and fixed in aqueous Bouin for two hours. Following this procedure, the pieces were dehydrated, embedded in Leica historesin and inblocked in the same resin in which catalyzer had been added. After resin polymerization, the blocks were cut into 4-6 $\mu \mathrm{m}$ slices, put in histological slides, and stained with hematoxylin-eosin (HE). For secretion characterization by Sudan black and Nilo's blue, glands of workers and queens at ages mentioned above of $S$. postica and A. mellifera were analyzed. The staining was conducted in total preparations: the glands were dissected in buffered saline solution for insects and put in histological slides covered with a film of poly-lysine to promote the glands adhesion to the slide. Subsequently they were fixed in $1 \% \mathrm{Ca}$ formol and stained with the stains for lipids mentioned above. The preparations were mounted in glycerinated gelatine, examined and photographed.

\section{RESULTS}

\section{Morphology}

The CSG are of ectodermic origin, having the alveoli and lumen ducts covered with cuticle. The duct cuticle has spiral reinforcements that prevent the lumen from collapsing. Our analysis has shown that $S$. postica and $A$. mellifera share most of the general histological characteristics of the CSG.

\section{Apis mellifera}

The walls of the alveoli and ducts of the CSG of workers, queens and newly emerged males are constituted by an epithelium of cubic cells that have large nuclei (occupying most of the cytoplasm) with very conspicuous nucleoli (Figs 1-3). The alveoli and lumen ducts are narrow in newly emerged workers and males (Figs 1 and 3), becoming wider in forager workers (Fig. 2) and egg-laying queens.

In sexually mature males, the CSG is much reduced and covered with fat body cells. The cells that form the alveoli are flat; even though some cells have conspicuous nucleoli, most cells do not, what is evidenced by their homogeneously stained nuclei (Fig. 4).

\section{Scaptotrigona postica}

The alveolar cells of newly emerged and nurse workers and virgin queens are predominantly cubic. In this phase, there is little or no secretion in the lumen. The nuclei are basal and contain visible nucleoli (Fig. 5). In forager workers and egglaying queens the alveolar cells are predominantly flat, with homogeneously staining nuclei and cytoplasm weakly stained by the hematoxylin and eosin. In the apical region, the cytoplasm appears acidophil (Fig. 6).

In this species, the duct cells are invariably flat with small nuclei and sometimes visible nucleoli. The lumen is covered with cuticular spiral reinforcements (Fig. 5). The salivary pouch is formed by flat cells. The cytoplasm of these flat cells stain strongly with eosin and contain nuclei that are very well structured (Fig. 6).

\section{Secretion}

The glandular cells of newly emerged workers of both species stain blue with Nile's blue (Fig. 7) and black with Sudan (Fig. 8). Nevertheless, the alveoli contain little or no secretion in the lumen, and are collapsed. Few secretions stain pink with Nile's blue in the ducts of $S$. postica (Fig. 7). The limits between the gland cells of newly emerged workers of A. mellifera are possible to differentiate with Sudan Black stain (Fig. 8).

In nurse workers and virgin queens of both species most of the alveolar cells accumulate secretion and some alveoli are turgid, with the secretion in the lumen stained pink with Nile's blue (Figs 9 and 10).

Forager workers and egg-laying queens of both species have turgid alveoli, full of secretion stained black with Sudan (Fig. 11) and rose-reddish with Nile's blue (Fig. 12). In glands stained with Nile's blue, the cell limits appear dark-blue and the cytoplasm appears red. In the central portion of the cell, a non-stained region reveals the position of the nucleus (Fig. 12).

\section{DISCUSSION}

The shape of the duct cells varies between species. Workers and queens of $S$. postica have flat cells in all age groups. By contrast, only sexually mature males of $A$. mellifera have flat cells; newly emerged workers, queens and males have cubic cells.The reinforcements avoid the collapse lumen duct (GraF 1968).

The salivary pouch of $S$. postica is formed by flat to cubic cells that have nuclei with evident nucleoli and acidophilic cytoplasm. The function of the pouch is unknown. According to CRUz-LANDim (1967), it is a vestige of the flat, tapeworm-like common excretory duct of the salivary glands of bees that do not have a CSG.

Histological analyses of the CSG show that the morphology of the alveolar cells is generally uniform within and between species. The variation in cell shape displayed by $S$. postica, changing from cubic in newly emerged and nurse workers to flat in foragers, is due to a stretching of the alveolar epithelium to accommodate the secretions that accumulate in the lumen. A similar change in cell shape occurs in males of A. mellifera: the cells are cubic in the young and become flat as the bee ages. In the latter individuals, however, the alveoli lumen appears collapsed and the cell nuclei picnotic, and the change in shape is attributed to cellular degeneration. Flat alveolar cells are associated with low or absent gland activity, as in the case of forager workers of $S$. postica, or also occur in glands that are in a regressive process, as in the sexually mature males of $A$. mellifera. SALLES \& CRUZ-LANDIM (1998) observed similar morphologic alterations in the CSG of Camargoia nordestina Moure, 1989: young workers had columnar alveolar cells and old workers, cubic or flat cells. 

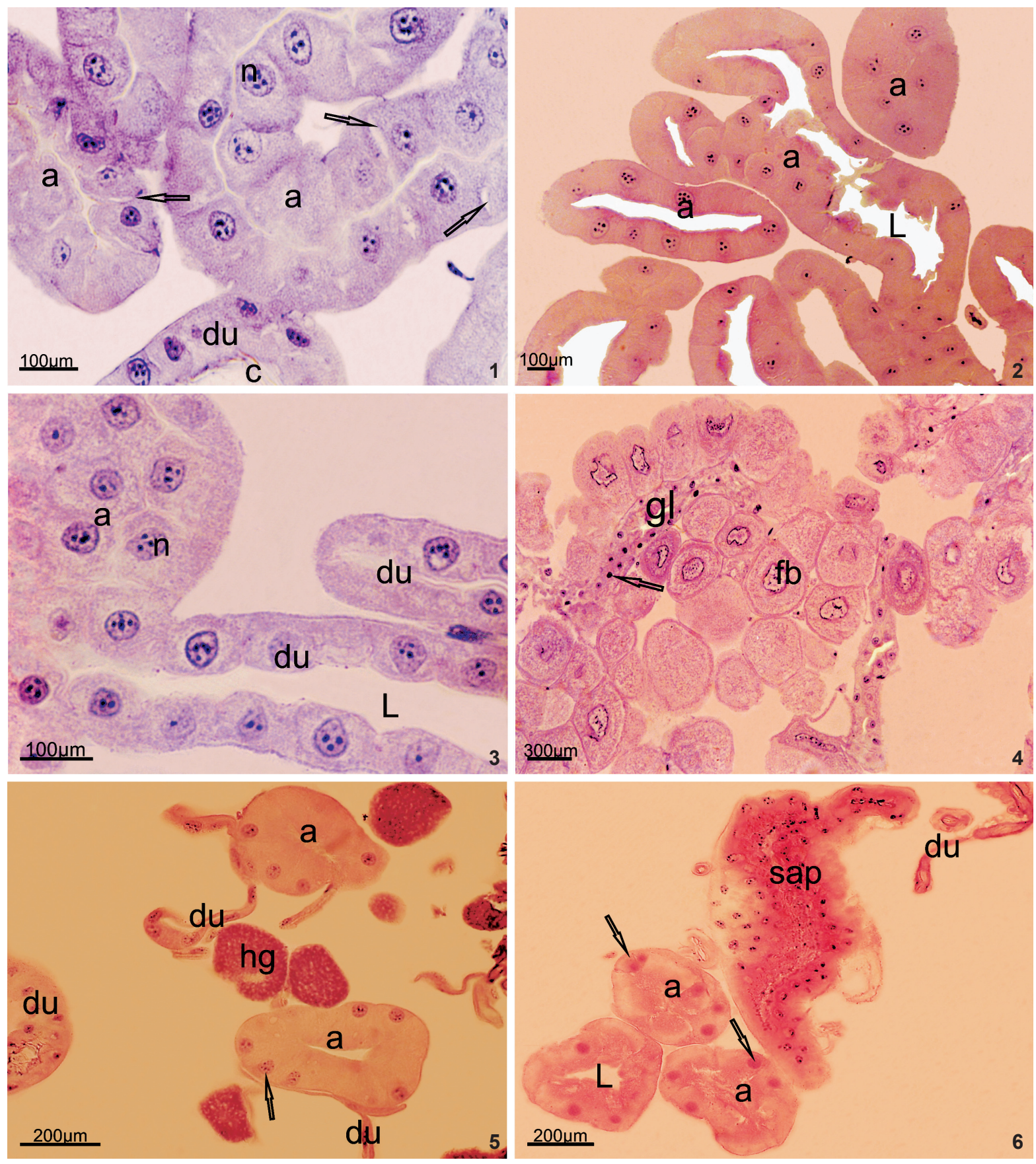

Figures 1-6. Cephalic salivary glands (CSG) stained with HE. (1-4) A. mellifera: (1) newly emerged worker showing alveoli (a) and ducts (du) with collapsed lumen, cells with central nuclei ( $n$ ) and visible nucleoli. Open intercelullar spaces (arrows) and duct cuticle reinforcements (c). (2) CSG from forager worker showing alveolar walls consisting of cubic cells and wide alveolar lumen (L). (3) CSG form a newly emerged male showing the gland histology similar to young females, and a sexually mature male's (4) degenerated gland (gl) showing glandular cells with picnotic nuclei (arrows), surrounded by fat body cells (fb). (5-6) Scaptotrigona postica: (5) CSG from nurse worker showing weakly stained alveolus (a) cells presenting nuclei (arrows) with nucleoli and duct (du) wall consisting of flat cells; (6) CSG from egg-laying queen showing the very acidophilic cells of the salivary pouch (sap) and alveoli (a) with cubic wall cells and homogenous nucleus (arrows). (a) Alveoli, (du) duct, (fb) fat body, (hg) hipopharingeal gland, (L) lumen, (sap) salivary pouch. 
The fact that the amount of secretion accumulated in the alveoli lumen increases with time suggests that it is stored for latter use. In workers, the use of accumulated secretions starts when intra-nidal activities are replaced with extra-nidal activities; in queens, it starts with the oviposition period.

The alveolar cells of the workers of $S$. postica go through more striking modifications than those of A. mellifera in the different phases of the bees' lives. Newly emerged workers present homogeneously stained cell nuclei that occupy most of the cytoplasm. This is typical of cells that are in differentiation process, not yet producing secretion, or producing small amounts of it.

Cruz-Landim (1967) identified two different types of alveoli in the CSG of $S$. postica. One is formed by cells with large basal nuclei and basophilic cytoplasm, while the other is formed by more eosinophilic cells. The different alveoli types found by that author seem to correspond to the two forms found in the present study. However, we think that they correspond to different functional phases of the alveolus rather than two different kinds of alveoli. The alveoli with basophilic cytoplasm observed by CRUZ-LANDIM (1967) are found in the glands of nurse workers, whereas the alveoli with eosinophilic apical cells are found in glands of forager workers.

The CSG of middle aged Plebeia emerina Schwarz, 1938 workers (SANTOS et al. 2009) have alveoli with a wide lumen. In foragers, the lumen is reduced. This contrasts with our findings for S. postica and A. mellifera. Plebeia emerina middle aged workers use their jaws to macerate small balls of propolis that are dispersed through the colony. SANTOS et al. (2009) suggested that secretion from the CSG is mixed with the propolis during maceration, and that it helps to maintain propolis viscosity. Propolis ball maceration was not observed in S. postica and $A$. mellifera workers. Nevertheless, it is possible that the CSG secretion have a similar role in propolis collection and transportation to the colony, because larger stocks of secretion are present in the glands of foragers.

Most social interactions occur between workers and queens. Males have low activity levels inside A. mellifera colonies (FreE 1980). This may explain the low development of the CSG in males, and a total degeneration of the gland in sexually mature individuals that are leaving the colony. The more active individuals, and those with dominant roles in the social hierarchy, have larger, more varied, more numerous and better developed glands. Because males have limited functions in the colony and few social interactions, their CSG glands are under-developed or absent.

Sudan Black stains any substance of a lipid nature black or greenish-gray. The Nile's blue sulfate is a mixture of three stains with different colors that dissolve differently according to lipid composition: neutral lipids stain pink, acid lipids and some other non lipid cell components stain blue (MELlo \& VIDAL 1980). The simultaneous use of the two stains in our study allowed us to characterize the secretion as consisting of neu- tral lipids. The neutral lipids are derivatives of fat acids, which originate from hydrocarbons (LeHNINGER et al. 2000).

Some pheromones, as for example the one present in the queen's substance of $A$. mellifera, are composed by fat acids (Barbier \& Lederer 1960, Callow \& Johnston 1960). Hydrocarbons are frequent components of bee gland secretion, as for example the Dufour gland of workers of both species A. mellifera (Katzav-Gozansky et al. 1997) and Melipona bicolor Lepeletier, 1836 (ABDALla et al. 2004). They are also present in the cuticle and seem to have a "fingerprint" function (BlOMQUist et al. 1998). Furthermore, hydrocarbons are found in the hemolymph of bees. Kullemberg et al. (1973) and Arnold et al. (1996) detected these compounds in the CSG secretion. It is possible that at least some hydrocarbons are absorbed from the hemolymph through the open intercellular spaces of the alveolar epithelium seen in the ultrastructural sections (PoIANI \& Cruz-Landim 2009), thus becoming part of the CSG secretion.

HeselHaus (1922) suggested that the function of the CSG secretion is to soften the wax during nest construction. SIMPSON (1960) questioned this interpretation based on the argument that secretions of a similar consistency are produced by the glands of bees that do not build with wax. The latter proposed that the function of the CSG secretion is to lubricate the mouthparths. Nevertheless, bee glands present great plasticity among species, caste, and sexes, consistent with bees' behavioral plasticity. For this reason, the hypothesis that the CSG functions in wax manipulation in A. mellifera and S. postica workers cannot be discarded based on the argument that the queens and males of these species have active glands that exude a secretion of similar properties but nonetheless do not work with wax. The probable function of the secretion in P. emerina (SANTOS et al. 2009), for example, is an example of the plasticity of the CSG gland. Furthermore, substances other than wax can be more easily manipulated with the help of the glands' secretion. Forager bees collect several materials from plants, some of which are insoluble in water (latex, resins and fragrances; Armbruster \& Webster 1979, Roubiк 1992, Schmidt 1997) and soluble in oil (SANTos et al. 2009), and the CSG secretion could potentially assist in the collection and manipulation of these substances. In this sense, several functions may be thought possible for the CSG secretion.

Apis mellifera and Scaptotrigona bipunctata workers discriminate between nestmates and non-nestmates workers. Nestmate recognition is possible, at least in part, due to cuticular hydrocarbons (Moritz \& Hillesheim 1990, Page et al. 1991, JUNGNICKEL et al. 2004). When introduced into a foreign colony, newly emerged workers of $A$. mellifera are not rejected, whereas middle aged and forager workers are. ARNold et al. (1996) showed that some hydrocarbons detected in the CSG of A. mellifera are also found in the epicuticle. Knowing that hydrocarbons on the outer body surface get worn out during flight (BAGNÈres \& Morgan 1990), we hypothesize that forager workers spread the CSG secretion over their bodies (with the help of their legs) in order to replace lost cuticular hydrocarbons. This behavior 

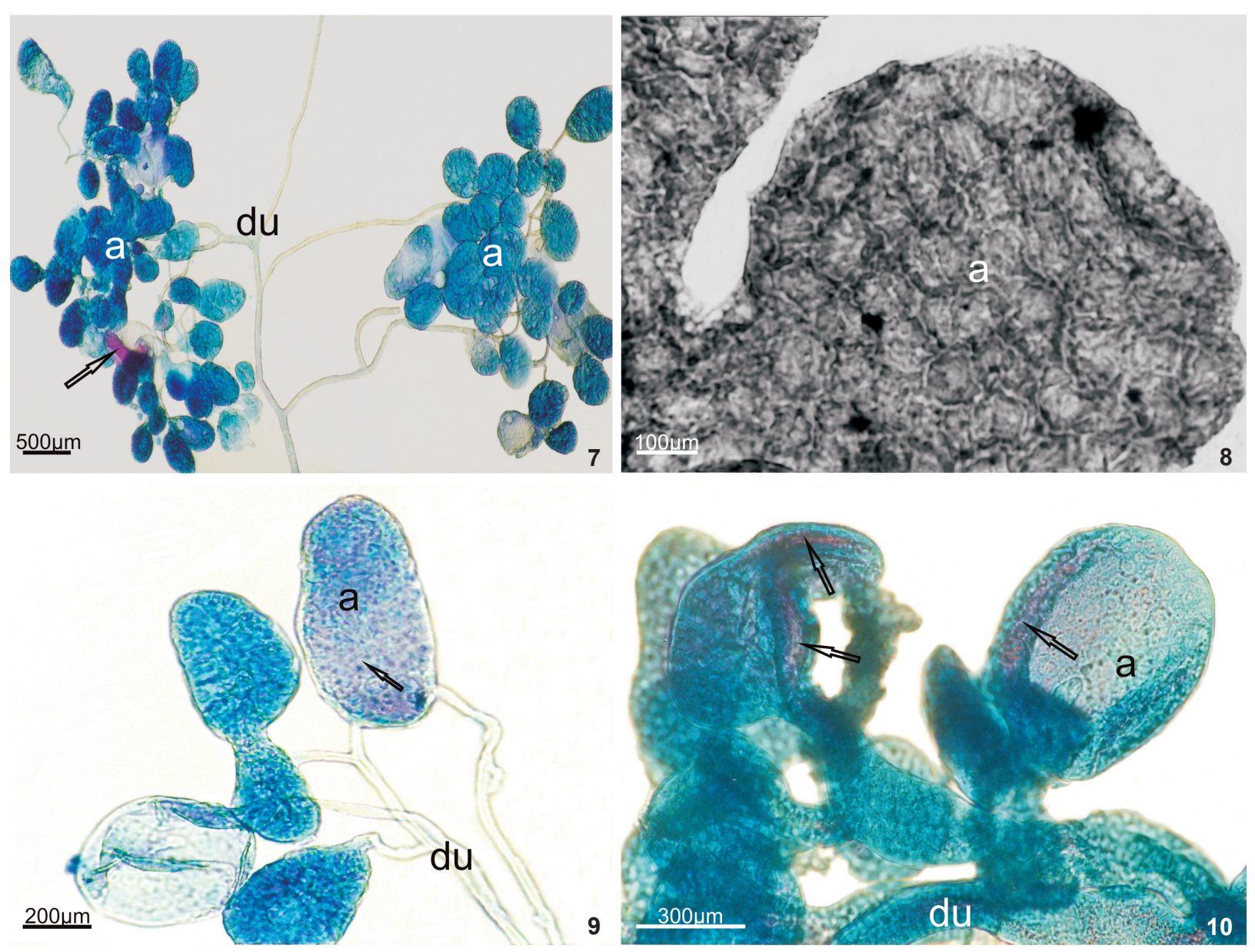

9
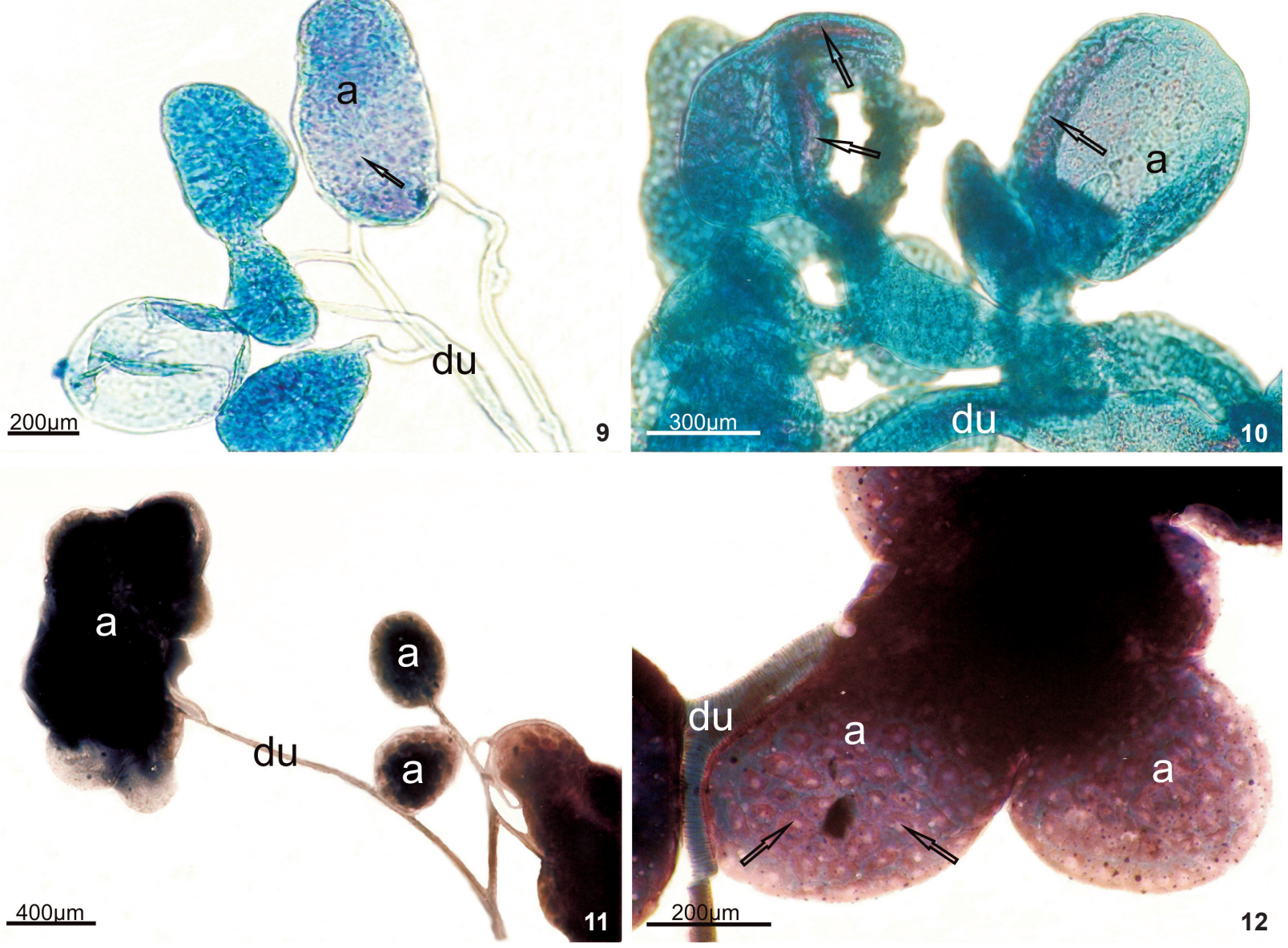

Figures 7-12. Total mounts of cephalic salivary glands (CSG): (7) CSG from newly emerged worker of Scaptotrigona postica showing secretion (arrow) stained pink with Nile's blue. (8) Alveolus (a) from newly emerged worker of Apis mellifera stained with Sudan black, without secretion in the lumen, showing the cells limits and grayish cytoplasm. (9-10) Secretion (arrows) stained pink with Nile's blue in nurse workers of S. postica and virgin queen of $A$. mellifera, respectively. (11) CSG from forager worker of S. postica with the alveoli (a) full of secretion stained black with the Sudan black. (12) Forager worker of $A$. mellifera showing dark-red secretion in the alveoli (a) satained by Sudan Black. Arrows indicate nucleus location. (a) Alveoli, (du) duct. 
would ensure that forager workers are recognized when they return to their colonies.

Fragrances associated with nectar and opening flowers are attractive for forager bees. A fraction of the volatile compounds that constitute the floral scent can dissolve in the cuticular waxes and become incorporated into the body surface, helping bees to learn and discriminate among several flower species (Masson 1982, Phan-Delegue et al. 1986). The floral fragrances contain more than a hundred compounds including hydrocarbons (Williams \& Whitten 1983, PAhn-Delegue et al. 1986). If the secretion produced by the CSG is dispersed on the bee's body surface and if the hydrocarbons contained in this secretion are able to absorb floral fragrances, it can be hypothesized that gland's secretion also functions in the establishment of the colony's identity, by enabling the acquisition of particular scents originated from food stocks. FreE (1980) attributes the particular scent of bees to the cuticular wax absorption of smells from colony food stocks.

Stingless bees adopt several systems of nestmate recruitment for foraging food (Lindauer \& KerR 1960, EsCH 1967). The recruits of $S$. postica follow a scent trail deposited by the recruiting bees (Lindauer \& KeRR 1960). Despite the fact that mandibular glands are considered the most probable head gland source of trail pheromones, JARAU et al. (2004) and SCHORKOPF et al. (2007) demonstrated that, in Trigona recursa Jurine, 1807 and T. spinipes, respectively, the pheromones used to build the scent trail come from the CSG. Therefore, is possible that the secretion of the CSG is an additional source of pheromones and is consequently involved in food source communication in S. postica.

In spite of the fact that the CSG of A. mellifera and S. postica present some differential histological features, gland secretion has similar physical properties, and gland developmental cycle follows a similar pattern in both species, being best developed in the foragers. These results raise questions that can be investigated under several apprises, such as the possible role of the CSG in food source communication, nestmate recognition, and identification of the "queen status" in intra-caste interactions. On the other hand, the deterioration of the CSG gland in sexually mature males of $A$. mellifera is an indication that its secretions are no longer necessary in this phase.

\section{ACKNOWLEDGEMENT}

The authors acknowledge the financial support from Coordenação de Aperfeiçoamento de Pessoal de Nível Superior.

\section{LITERATURE CITED}

Abdalla, F.C.; G.R. Jones; E.D. Morgan \& C. Cruz-Landim. 2004. Chemical composition of Dufour gland secretion in queens of Melipona bicolor (Hymenoptera, Meliponini). Journal of the Brazilian Chemical Society 15: 621-625.

Armbruster, W.S. \& G.L. Webster. 1979. Pollination of two species of Dalechampia (Euphorbiaceae) in Mexico by euglossine bees. Biotropica 11: 278-283.

Arnold, G.; B. Quenet; J.M. Cornuet; C. Masson; B.De Schepper; A. Estoup \& P. Gasqui. 1996. Kin recognition in honey bees. Nature 379: 498. doi: 10.1038/379498a0.

Bagnères, A.G. \& E.D. Morgan. 1990. A simple method for analysis of insect cuticular hydrocarbons. Journal of Chemical Ecology, 16: 3263-3276.

BARBier, M. \& E. LeDERER. 1960. Structure chimique de la "substance royale" de la reigne d'abeille (Apis mellifera L.). Comptes Rendus de L'Academie des Sciences, Paris 250: 4467-4469.

Bergman, P. \& G. Bergström. 1997. Scent marking, scent origin, and species specificity in badly premating behavior of two scandinavian bumblebees. Journal of Chemical Ecology 23: $1235-1251$.

Blomquist, G.J.; J.A. Tillma; S. Mpuru \& S.J. Seybold. 1998. The cuticule and cuticular hydrocarbons of insects: Structure, function and biochemistry, p. 34-54. In: R.K. VANDER MEer; M.D. Breed; M.L. Winston \& K.E. Espelie (Eds). Pheromone communication in social insect. London, Westview Press, 230p.

CALlow, R.K. \& N.C. Johnston. 1960. The chemical constitution and synthesis of queen substance of honeybees (Apis mellifera L.). Bee World 41: 152-153.

Cruz-Landim, C. 1967. Estudo comparativo de algumas glândulas das abelhas (Hymenoptera, Apoidea) e respectivas implicações evolutivas. Arquivos de Zoologia 15 (3): 177-290.

Cruz-Landim, C. \& M.L.S. Mello. 1967. The Post-Embryonic Changes in Melipona quadrifasciata anthidioides Lep. (Hymenoptera, Apoidea). II. Development of Salivary Glands System. Journal of Morphology 123: 481-502.

Delage-Darchen, B.; S. Tabec \& R. Darchen. 1979. Secretion Enzymatique des Glandes Salivaires et de L'Intestin Moyen d'une Abeille Sans Dard, Apotrigona nebulata (Sur.) (Hyménoptères, Apidés). Annales des Sciences Naturelles Zoologie et Biologie Animale 13: 261-267.

Esch, H. 1967. Bedeutung der Lauterzeugung für die Verständigung der stachellosen Bienen. Zeitschrift fur Vergleichende Physiologie 56: 408-411.

FreE, J.B. 1980. A organização social das abelhas (Apis). São Paulo, Editora da Universidade de São Paulo, 79p.

Graf, V. 1968. Observações sobre o canal salivar cefálico de alguns Apidae. Boletim da Universidade Federal do Paraná 3: 65-78.

Heselhaus, F. 1922. Die Hautchüsen der Apiden und Verwandter formen. Zoologische Jahrbuecher Abteilung fuer Anatomie und Ontogenie der Tiere 43: 363-464.

Jarau, S.; M. Hancir; R. Zucchi \& F.G. Barth. 2004. A Stingless Bee Uses Labial Gland Secretions for Scent Trail Communication (Trigona recursa Smith, 1863). Journal of Comparative Physiology A-Neuroethology Sensory Neural and Behavioral Physiology 190 (3): 233-239.

Jungnickel, H.; A.J.S. da Costa; J. Tentschert; E.F.L.R.A. Patricio; V.L. Imperatriz-Fonseca; F. Drijphout \& E.D. Morgan. 2004.

ZOOLOGIA 27 (6): 979-985, December, 2010 
Chemical basis of inter-colonial aggression in stingless bee Scaptotrigona bipunctata (Hymenoptera: Apidae). Journal of Insect Physiology 50: 761-766. doi: 10.1016/ j.jinsphys.2004.05.011.

KatzaV-Gozansky, T.; V. Soroker; A. Hefetz; M. Cojocaru; D.H. Erdmann \& W. Francke. 1997. Plasticity of caste-specific Dufour's gland secretion in honey bee (Apis mellifera L.). Naturwissenschaften 84: 238-241. doi: 10.1007/s001140050386.

Kratky, E. 1931. Morphologie und Physiologie der Drüsen in Kopf und Thorax der Honigbiene (Apis mellifera L.). Zeitschrift Fur Wissenschaftliche Zoologie 139: 120-200.

Kullemberg, B.; G. Bergström; B. Bringer; B. Calberg \& B. Cederberger. 1973. Observation of scent marking by Bombus Latr. and Psithyrus Lep. Males (Hym., Apidae) and localization of site of production of secretion. Zoon 1: 23-30.

LAUER, S.M.S. 1992. Estrutura macro e microscópica das glândulas do sistema salivar nas castas de Bombus atratus Franklin (Hymenoptera, Apidae), p. 237-238 In: A.E.E. Soares \& D.DE Jong (Eds). Pesquisas com abelhas no Brasil. Ribeirão Preto, Sociedade Brasileira de Genética, 680p.

Lehninger, A.L.; D.L. Nelson \& M.M. Cox. 2000. Princípios de Bioquímica. São Paulo, Sarvier, 839p.

Lindauer, M. \& W.E. Kerr. 1960. Communication between workers of stingless bees. Bee World 41: 29-41 and 65-71.

Masson, C. 1982. Physiologie sensorielle et comportement of l'abeille. Comptes Rendus de L'académie D'agriculture 1982: 1350-1361.

Mello, M.L.S. \& B.C. Vidal. 1980. Práticas de Biologia Celular. São Paulo, Edgard Blücher, 71p.

Moritz, R.F. \& E. Hillesheim. 1990. Throphallaxis and genetic variance of kin recognition in honey bees, Apis mellifera L. Animal Behaviour 40: 641-647.

Page Jr, R.E.; R.A. Metcalf; R.L. Metcalf; E.H. Erickson Jr \& R.L. LAMPMAN. 1991. Extractable hydrocarbons and kin recognition in honey bee (Apis mellifera L.). Journal of Chemical Ecology 17: 745-756.

Pahn-Delegue, M.H.; C. Masson; P. Etievant \& M. Azar. 1986. Selective olfatory choices of honeybee among sunflower aro- mas: a study by combined olfatory conditioning and chemical analysis. Journal of Chemical Ecology 12: 781-793.

Poinni, S.B. \& C. Cruz-Landim. 2009. Cephalic salivary gland ultrastructure of worker and queen eusocial bees (Hymenoptera, Apidae). Animal Biology 59: 299-311.

RoubiK, D.W. 1992. Ecology and Natural History of Tropical Bees. Cambridge.,Cambridge University Press, 514p.

Salles, H.C. \& C. Cruz-Landim. 1998. Levantamento das glâdulas exócrinas presentes em Camargia nordestina Moure, 1989 (Hymenoptera, Apidae, Meliponinae) Revista Brasileira de Entomologia 41 (2-4): 297-302.

Santos, C.G.; F. Megiolaro; J.E. Serrão \& B. Blochtein. 2009. Morphology of the head salivary and intramandibular glands of the stingless bee Plebeia emerina (Friese) (Hymenoptera, Meliponini) workers associated with propolis. Annals of the Entomological Society of America 102: 137-143.

Schmidt, J.O. 1997. Bee products: Chemical composition and application, p. 213-220. In: A. Mizrahi \& Y. Lensky (Eds). Bee products: properties, applications and apitherapy. New York, Plenum Press, 269p.

Schorcopf, D.L.P.; S. Jarau; W. Francke; R. Twele; R. Zucchi; M. Hrncir; V.M. Schmidt; M. Ayasse \& F.G. Barth. 2007. Spitting out information: Trigona bees deposit saliva to signal resource locations. Proceedings of the Royal Society B-Biological Sciences 274: 895-898. doi: 10.1098/rspb.2006.3766.

Simpson, J. 1960. The Functions of Salivary Glands of Apis mellifera. Journal of Insect Physiology 4 (2): 107-121.

Simpson, J. 1962. The Salivary Glands of Apis mellifera and Their Significance in Caste Determination. Symposia Genetica et Biologica Italica 10: 173-188.

Simpson, J.; I.B.M. Riedel \& N. WiLding. 1968. Invertase in Hypopharyngeal Gland of Honeybee. Journal of Apicultural Research 7 (1): 29-36.

SNODgRass, R.E. 1956. Anatomy of honey bee. New York, VailBallow Press, 334p.

Williams, N.H. \& W.M. Whitten. 1983. Orchid floral fragrances and male euglossine bees: Methods and advances in last sesquidecade. Biological Bulletin 164: 355-395.

Submitted: 28.VIII.2009; Accepted: 15.II.2010.

Editorial responsibility: Lucélia Donatti 